\title{
The Effects of Tongue Strength on Speech Production Skills in Children with Cerebral Palsy
}

\author{
Youngmee Lee ${ }^{\mathrm{a}}$, Pil Yeon Jeong ${ }^{\mathrm{b}}$, Jee Eun Sung ${ }^{\mathrm{b}}$, Hyun Sub Sim ${ }^{\mathrm{b}}$ \\ ${ }^{a}$ Department of Communication Disorders, Tongmyong University, Busan, Korea \\ ${ }^{b}$ Department of Communication Disorders, Ewha Womans University, Seoul, Korea
}

Correspondence: Hyun Sub Sim, PhD Department of Communication Disorders, Ewha Womans University, 52 Ewhayeodae-gil, Seodamun-gu, Seoul 03760, Korea Tel: $+82-2-3277-3538$

Fax: +82-2-3277-2122

E-mail: simhs@ewha.ac.kr

Received: September 28, 2018

Revised: November 17, 2018

Accepted: November 28, 2018

This work was supported by the R \& D program of MKE/KEIT (No. 10036461, Development of an embedded key-word spotting speech recognition system individually customized for disabled persons with dysarthria)

This work was included some contents from the paper presented in 2012 at the conference of the Korean Academy of Speech-Language Pathology and Audiology.

\begin{abstract}
Objectives: The aims of this study were to examine the tongue strength of children with cerebral palsy (CP) and to identify the relationship between tongue strength and speech production skills at word level in children with CP. Methods: Twenty children with CP participated in this study, and they ranged in age from 5 to 15 years. The children were median-split into two groups (children with higher tongue strength vs. children with lower tongue strength) based on maximal tongue strength. The maximal tongue strength was obtained using the lowa Oral Performance Instrument. The speech production skills were measured using the Assessment of Phonology and Articulation for Children, and the percentage of consonants correct (PCC) of all children was calculated according to the place and manner of articulation. Results: Children with higher tongue strength obtained significantly higher PCC than children with lower tongue strength. The maximal tongue strength was significantly correlated with PCC of all places and manners of articulation (all $p<.01$ ). Maximal tongue strength was a significant predictor of speech production skills in children with CP. Conclusion: Children with higher tongue strength had significantly better speech production skills than children with lower tongue strength. Tongue strength was an important factor accounting for individual differences in speech production skills for children with CP. The results indicate that tongue strength may serve as a clinically critical index in predicting speech production skills in children with CP.
\end{abstract}

Keywords: Cerebral palsy, Children, Tongue strength, Speech production skills 뇌성마비(cerebral palsy)는 뇌 발달의 미성숙 혹은 손상으로 인 해서 발생되는 운동장애 및 자세장애이다(Workinger, 2005). 말 산출과 관련된 근육의 마비, 약화, 불협응으로 인해 마비말장애 (dysarthria)가 동반될 경우, 뇌성마비 아동의 말명료도(speech intelligibility)가 저하되는 양상을 보이게 된다(Ansel \& Kent, 1992; Caruso \& Strand, 1999). 뇌성마비 아동의 의사소통에서 나타나는 구어적·비구어적 결함의 양상은 다양하며, 이러한 결함이 말명료 도에 부정적인 영향을 미치는 것으로 보고되었다(Caruso \& Strand, 1999; Morris \& Klein, 1987). Caruso와 Strand (1999)는 뇌 성마비 아동의 말 산출 하부 시스템의 결함이 음질, 음도, 강도와 같은 발성의 손상, 자음과 모음의 오조음, 과다비성(hypernasality), 말속도 조절의 문제와 같은 구어적 결함을 야기시킨다고 하였다.
Morris와 Klein (1987)은 뇌성마비 아동의 구강기능에서 입술 뒤 로 당기기(lip retraction), 턱 내밀기(jaw thrust), 긴장성 깨물기(tonic bite), 혀 뒤로 당기기(tongue retraction), 혀 내밀기(tongue thrust) 등과 같은 병리적 패턴이 나타나며, 이로 인해 구강운동의 정교한 조절이 어렵고 운동범위가 제한적이라고 언급하였다.

임상 현장에서는 뇌성마비 아동의 말명료도 향상을 위해서, 구 어적인 접근과 비구어적 구강운동 접근(nonspeech oral motor treatment)을 함께 실시하고 있다(Muttiah, Georges, \& Brackenbury, 2011). 비구어적 구강운동 접근을 뇌성마비 아동에게 실시할 경우, 정상적인 구어 산출을 촉진하기 위해 구강운동 및 섭식기술 향상과 같은 목표를 설정하고, 혀, 턱, 입술의 움직임과 관련된 활동 을 위주로 진행하게 된다(Lee \& Kim, 2017; Workinger, 2005). Mut- 
Youngmee Lee, et al. • The Effects of Tongue Strength on Speech Production Skills

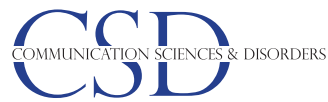

tiah 등(2011)이 언어재활전문가와 연구자에게 일대일 인터뷰를 하 여 비구어적 구강운동 접근의 효과에 대한 의견을 진행한 결과, 언 어재활전문가는 비구어적 운동 접근에 대해 말 산출 능력 개선에 효과가 있으며, 임상현장에서 사용하기에 충분한 근거를 지닌 중재 (evidence-based practice)라고 언급하였다. 반면에, 언어병리학 연 구자는 비구어적 구강운동 접근이 말 산출 능력에 미치는 효과가 확실하지 않다는 견해를 보였으며, 비구어적 구강운동 능력과 말 산출 능력과의 연관성을 입증하는 타당한 연구결과가 좀 더 축적 되어야 한다는 견해를 보였다. 이처럼, 비구어적 구강운동 접근의 실시에 대해 지지하는 입장과 그렇지 않은 입장이 있으며, 이러한 견해 차이는 조음기관의 강도 훈련의 효과, 구강운동과 말 산출 간 의 관련성, 비구어적 구강운동의 단독 훈련을 통한 말 산출 능력의 개선 여부, 초기 섭식행동과 말 산출 간의 관련성 등의 이슈들과 관 련되어 있다(Watson \& Lof, 2008). 즉, 비구어적 구강운동을 지지 하는 입장에서는 임상적 경험의 축적에 근거하여 다양한 장애군에 서 구강운동을 통해서 말 산출 능력의 개선이 가능하다고 주장하 고 있으며, 비구어적 구강운동을 지지하지 않는 입장에서는 타당 하고 강력한 중재 효과가 입증된 경우에만 중재 전략으로 사용할 수 있다고 주장하고 있는 것이다(Watson \& Lof, 2008).

언어병리학 연구자 사이에서도 비구어적인 구강운동 능력과 말 산출 능력과의 관련성에 대해서는 상반된 견해를 보고하고 있다 (Chang, Sim, \& Kwon, 2012; Hiiemae \& Palmer, 2003; Jeong \& Sim, 2015; Love, Hagerman, \& Taimi, 1980; Steeve, Moore, Green, Reilly, \& McMurtrey, 2008). Workinger (2005)는 구강운동 능력과 말 산출 능력 간에 관련성이 있다는 입장에서 말장애 아동의 구어 산출을 위해서 비구어 구강운동 능력 습득에 역점을 두어야 한다 고 언급하였다. Ray (2001)도 경직형 뇌성마비 아동에게 혀, 입술, 턱의 적절한 위치를 바로잡고 기능을 향상시키기 위한 중재를 실시 한 결과에서 구강운동 기능과 말명료도가 모두 향상되는 결과를 보였다는 점을 근거로 언급하면서, 비구어 구강운동 훈련이 뇌성마 비 아동의 말명료도 향상을 위해서 필요하다고 강조하였다. 국내 선행연구(Jeon \& Seo, 2007; Kim, Kim, \& Shin, 2008)에서도 호흡 과 구강운동 훈련을 병행했을 때, 취학전 경직형 뇌성마비 아동의 조음기관 기능, 자음산출 능력, 발성지속시간이 증가함으로써 구 강훈련이 뇌성마비 아동에게 효과적이라고 보고하였다. 또한, 섭식 능력과 관련해서도 뇌성마비 아동의 비정상적인 구강운동은 말명 료도와 상관이 있다는 결과를 제시하여 비구어적 구강운동과 말 산출 간에 관련이 있음을 제안한 바 있다(Chang et al., 2012; Jeong \& Sim, 2015). 반면에, 일부 연구자는 비구어 구강운동 기능이 말 산출 능력과 관련성이 있다는 충분한 근거가 부족하기 때문에, 중
재 시 비구어 구강운동 접근의 선택과 적용에 신중한 입장을 취해 야 한다고 주장하고 있다(Hiiemae \& Palmer, 2003; Steeve et al., 2008). Bunton (2008)은 비구어 구강운동과 말 산출 시의 뇌 활성 화 양상이 다른 패턴을 보이기 때문에, 비구어적 구강훈련이 말 산 출 향상에 긍정적인 영향을 미친다고 보기 어렵다고 하였다. Mackenzie, Muir, Allen과 Jensen (2014)은 마비말장애 성인의 언어치료 에 비구어 구강운동을 포함시켰을 때 말명료도나 구강기능이 향상 되지 않았다고 보고하였다. 그리고 Morris와 Klein (2000)은 뇌성 마비 아동에게 섭식 문제와 말장애가 동반되는 경향이 있지만, 섭 식 문제 자체가 말장애의 발생 요인으로 보기는 어렵다고 하였다. 이러한 견해에서는 비구어 운동기능과 구어 운동의 조절 체계가 다르기 때문에, 상호 간에 영향을 미치기 어렵다고 본다(Hiiemae \& Palmer, 2003; Steeve et al., 2008).

임상현장과 연구 분야에서 비구어적 운동기능과 말 산출 능력과 의 관련성에 대한 이견이 있음에도 불구하고, 국내외적으로 언어 재활전문가는 비구어적 운동기능 중 하나인 혀(tongue)의 운동기 능에 대한 평가와 중재를 실시하고 있다(Darley, Brown, \& Aronson, 1975; Lee, Sim, \& Kim, 2005; Ray, 2001; Van Lierde et al., 2012). 정확한 말소리를 산출하기 위해서는 혀가 일정한 강도를 유지하면 서 정확한 조음위치에 있어야 하며, 적절한 시간 구간 동안 빠르고 정확하게 움직여야 한다(Robin, Goel, Somodi, \& Luschei, 1992). 즉, 혀는 말 산출을 위한 주요한 조음기(articulator) 역할을 담당하 는 것이다. Mackenzie, Muir와 Allen (2010)의 연구에 따르면, 임상 현장에서 언어재활전문가의 약 $81 \%$ 가 구강훈련을 실시하고 있으 며, 특히 혀와 입술 훈련에 초점을 두고 있는 것으로 나타났다. 국내 에서도 Lee 등(2005)이 임상현장에서 마비말장애 성인의 혀 강도 와 운동범위(range of motion, $\mathrm{ROM}$ )를 평가하여 일반 성인보다 혀 근육이 약화되어 있다는 것을 파악하였으며, Choi와 $\operatorname{Sim}$ (2013)은 마비말장애 성인의 혀 강도와 말명료도와의 관련성을 분석하여 마 비말장애 성인의 조음중증도가 심할수록 혀 강도가 낮아지는 경 향을 확인하였다. Lee 등(2005)이 마비말장애 유무에 따른 성인의 혀 강도를 측정한 결과에서도 마비말장애 성인의 혀 강도가 일반 성인에 비해 유의하게 낮았다. 그리고 Murdoch, Attard, Ozanne와 Stokes (1995)는 말장애를 동반한 아동과 일반아동 간에 혀 강도가 유의한 차이가 나타내며, 혀 강도가 아동의 말 문제를 예측하는 기 능을 할수 있다고 언급하였다. 이러한 연구결과들은 마비말장애인 의 혀 강도가 정교한 혀의 움직임이 요구되는 말 산출 능력과 관련 이 있으며, 말장애군의 말 문제의 진단과 치료에 활용될 평가지표 가 될 수 있음을 의미한다.

앞서 언급한 바와 같이, 비구어적 구강운동 능력과 말 산출 능력 
간의 관련성에 대해 상반된 연구결과에도 불구하고, 임상현장에서 는 혀와 입술과 같은 구강운동 능력을 촉진하는 것이 말명료도 향 상에 긍정적인 영향을 미친다고 여기며 다양한 원인의 말장애 아 동과 성인에게 비구어적 운동 접근을 실시하고 있다(Mackenzie et al., 2010). 비구어 운동 능력과 말 산출 능력과의 관련성을 탐색하 는 선행연구에서는 대상자의 장애 유무, 장애 유형, 연령 등이 다양 하여, 대상자 특성에 따라 상이한 결과가 도출되었을 수도 있을 것 이다. 본 연구에서는 말장애와 구강운동 문제가 동반될 가능성이 높은 뇌성마비 아동의 혀 강도와 말 산출 능력 간의 관련성을 탐색 하여, 뇌성마비 아동의 평가와 재활 계획 수립에 필요한 정보를 언 어재활전문가에게 제공하고자 하였다. 이에 따라, 본 연구에서는 혀 강도가 뇌성마비 아동의 말 산출 능력에 유의한 영향을 미치는 지 살펴보기 위해서, 뇌성마비 아동의 집단을 혀 강도에 따라 구분 하여 집단 간의 자음정확도에 차이가 있는지 확인하고, 뇌성마비 아동의 혀 강도, 조음위치 및 조음방법에 따른 자음정확도 간의 관 련성에 대해서 알아보고자 하였다. 이에 따른 구체적인 연구질문 은 다음과같다.

첫째, 혀 강도로 구분한 집단(고, 저)에 따른 조음위치 및 조음방 법에서의 자음정확도에 유의한차이가 있는가?

둘째, 뇌성마비 아동의 혀 강도, 조음위치 및 조음방법에 따른 자 음정확도 간의 상관관계는 어떠한가?

셋째, 뇌성마비 아동의 혀 강도는 자음정확도를 예측하는 유의 한 변수인가?

\section{연구방법}

\section{연구대상}

본 연구는 경기도 소재의 재활병원에서 재활치료를 받고 있는 만 5 세부터 15 세 사이의 뇌성마비 아동(20명)을 대상으로 하였다. 구체적인 대상자 선정 기준은 (1) 의학적으로 뇌성마비 진단을 받 았으며, (2) 운동발달 및 구강기능 결함을 제외하고 시각과 청각에 문제가 없으며, (3) 실험과제를 이해하고 참여할 수 있는 언어 및 인 지 능력을 지닌 경우로 제한하였다. 본 연구에 참여한 대상자의 성 별은 남아 11 명, 여아 9 명이었으며, 평균 연령은 140.3 개월 $(\mathrm{SD}=29.7)$ 이었다. 대상자의 뇌성마비 유형은 경직형(spastic type) 19명, 혼합 형(mixed type) 1 명이었다. Lee, Koo, Jang, Park과 Sung (2006)은 뇌성마비 아동 중에서 경직형 뇌성마비 아동이 전체 뇌성마비 아 동 중에서 약 $87 \%$ 를 차지한다고 보고한 바 있다. 이처럼 높은 경직 형 뇌성마비 아동의 분포로 인하여, 본 연구에서 뇌성마비 아동이 상당수를 차지하게 되었다. 대상자의 말 산출 하부시스템의 차이
를 통제하기 위하여 경직형 뇌성마비 아동만을 대상자로 선정하였 다. 대상자 중에서 혼합형 1 명의 사례도 경직형과 운동이상형이 혼 합된 경우로 경직형 뇌성마비가 더 우세한 경우에 해당하였다. 그 리고 대상자 중에서 공명상에 문제를 보인 아동이 1 명 있었으나, 본 연구에서 분석하는 분절적 차원의 자음정확도에는 영향이 나타나 지 않은 것으로 판단되어 데이터 분석에 포함시켰다.

본 연구에서는 혀 강도에 따른 말 산출 능력의 차이를 살펴보기 위해서, 중앙치 반분법으로 뇌성마비 아동을 혀 강도가 높은 고집 단(10명)과 혀 강도가 낮은 저집단(10명)으로 분류하였다. 각 집단 의 혀 강도를 살펴보면, 고집단의 평균 혀 강도는 $19.8 \mathrm{kPa}(\mathrm{SD}=15.5)$, 저집단의 평균 혀 강도는 $6.0 \mathrm{kPa}(\mathrm{SD}=2.3)$ 이었다. 두 집단의 성별 을 살펴보면, 고집단은 남아 6 명, 여아 4 명, 저집단은 남아 5 명, 여아 5 명이었다. 평균 생활연령에서는 고집단은 143.6 개월 $(\mathrm{SD}=23.7)$, 저집단은 129.6 개월 $(\mathrm{SD}=32.8)$ 이었다. 뇌성마비 유형을 살펴보면, 고집단에서는 경직형이 9 명, 혼합형이 1 명, 저집단에서는 경직형이 10 명이었다. 대상자의 뇌성마비 중증도를 살펴본 결과, 고집단에는 경도 6 명, 중등도 2 명, 심도 2 명, 저집단에는 경도 5 명, 중등도 1 명, 심도 4 명이 분포되어 있었다. 대상자의 중복장애 유무에 대해서 살 펴본 결과, 총 7명의 아동이 지적장애(intellectual disability)를 진 단받았으며, 이들은 고집단에 3 명, 저집단에 4 명 분포되어 있었다. 집단 간 통제가 잘 이루어졌는지 확인하기 위해서 독립표본 $t$-검정 과 카이제곱(chi-square) 검정을 실시한 결과, 생활연령 $(t(18)=.379$, $p>.05)$, 성별 $\left(\chi^{2}(1)=.192, p>.05\right)$, 뇌성마비 유형 $\left(\chi^{2}(1)=.291, p>.05\right)$, 뇌성마비 중증도 $\left(\chi^{2}(2)=4.667, p>.05\right)$ 에서 집단 간에 유의한 차이 가 없었다. 두 집단의 성별, 생활연령, 뇌성마비 유형, 뇌성마비 중증 도에 대한 정보는 Table 1에 제시하였다.

Table 1. Participants' characteristics

\begin{tabular}{lcc}
\hline & High group $(\mathrm{N}=10)$ & Low group $(\mathrm{N}=10)$ \\
\hline Tongue strength (kPa) & $19.8 \pm 15.5(9-54)$ & $6.0 \pm 2.3(1-8)$ \\
Sex & 6 & 5 \\
Male & 4 & 5 \\
Female & $143.6 \pm 23.7(61-174)$ & $129.6 \pm 32.8$ (102-188) \\
Age $(\mathrm{mo})$ & & \\
Type of CP & 9 & 10 \\
Spastic & 1 & 0 \\
Mixed & & 5 \\
Severity of CP & 6 & 1 \\
$\quad$ Mild & 2 & 4 \\
Moderate & 2 & \\
Severe & & \\
\hline
\end{tabular}

Values are presented as mean $\pm S D$ (range). $\mathrm{CP}=$ cerebral palsy. 
Youngmee Lee, et al. • The Effects of Tongue Strength on Speech Production Skills

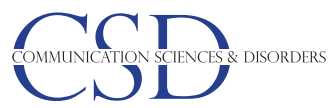

\section{연구도구}

본 연구에서는 대상자의 최대 혀 강도를 측정하기 위하여 Iowa Oral Performance Instrument (IOPI; IOPI Medical LLC, Carnation, WA, USA)를 사용하였으며, 조음위치 및 조음방법에 자음정 확도 산출을 위해서 아동용 발음평가(Assessment of Phonology and Articulation for Children, APAC; Kim, Pae, \& Park, 2007)를 사용하였다.

$|\mathrm{OP}|$

본 연구에서는 대상아동의 최대 혀 강도를 측정하기 위해서 IOPI 를 사용하였다. IOPI에는 압력 센서 회로(pressure-sensing circuitry), 피크 홀드 기능(peak-hold function), 타이머(timer)가 내부 장 치로 탑재되어 있으며, 공기가 들어 있는 작은 PVC 벌브(길이 3.5 $\mathrm{cm}$, 반경 $1.2 \mathrm{~cm}$ )에 가해지는 압력과 압력 유지 시간을 LCD (lightemitting diode) 창에 수치로 표시되도록 개발되었다. IOPI는 혀 강 도(tongue strength), 혀 지구력(tongue endurance), 입술 강도(lip strength)를 쉽고 간편하게 측정할 수 있도록 개발된 장치이며, 혀 와 입술 강도는 킬로파스칼 $(\mathrm{kPa})$ 로, 혀 지구력은 초(second) 단위 의 측정치로 제공한다. IOPI는 언어병리와 작업치료 분야에서 연 구와 임상 목적으로 사용되어 왔으며, 혀 강도 및 지구력, 입술 강도 에 대한 데이터를 신뢰롭게 제공하는 것으로 알려져 있다(Adams,

Mathisen, Baines, Lazarus, \& Callister, 2013; Choi \& Sim, 2013; Clark \& Solomon, 2012; Song, 2014; Vitorino, 2010). IOPI를 이용 한 혀 강도는 혀의 상하 및 좌우 움직임을 요구하지 않고 혀에 위치 한 벌브를 약 2-3초 동안 단순히 누르는 행위만으로 측정된다. 이러 한 혀 강도 측정의 원리로 인해서, 혀의 움직임의 범위가 제한적이 고 비정상적인 구강반사를 동반하기도 하는 뇌성마비 아동의 경우 도 혀 강도를 신뢰롭게 측정할 수 있도록 개발되었다.

\section{아동용 발음평가}

본 연구에서는 대상 아동의 자음정확도를 산출하기 위해서 AP$\mathrm{AC}$ (Kim et al., 2007)를 사용하였다. 본 검사는 2-6세 아동을 대상 으로 표준화 작업을 진행하여, 단어 수준에서의 아동 발음을 또래 아동과 비교하여 해석할 수 있도록 규준을 제공하고 있다. APAC 는 우리말 자음을 다양한 음운환경에서 검사할 수 있도록 1-4음절 의 친숙한 단어(37개)로 구성되어 있으며, 목표음소를 어두초성 (word-initial syllable-initial), 어중초성(word-medial syllable-initial), 어중종성(word-medial syllable-final), 어말종성(word-final syllable-final)의 네 가지 단어 내 위치에서 자음을 검사할 수 있도 록 되어 있다.

\section{연구절차}

본 연구는 서울 및 경기 지역 소재의 아동병원의 기관장과 언어 치료사에게 유선으로 연구 목적과 내용을 설명하고 협조를 얻어서 뇌성마비 아동을 섭외하였다. 이때, 대상 아동의 부모에게 연구 절 차에 대해서 충분히 설명한 후, 연구 참여에 동의한 대상자에 한해 서 검사를 진행하였다. 병원 내 조용한 언어치료실에서 개별 아동 에게 자음정확도를 평가하고 혀 강도를 측정하였다.

\section{혀 강도 측정}

아동이 편안하고 안정된 상태인 것을 확인한 후, IOPI에 연결된 공기가 주입된 작은 벌브를 아동의 경구개와 혀 사이에 위치하도록 하였다. 대상 아동은 자세보조 의자에 앉아 머리, 체간, 골반이 정 렬되는 바른 자세를 유지한 상태에서 벌브(bulb)를 2-3초 동안 혀 에 최대한 힘을 주어서 위쪽으로 누르도록 하였다. 최대 혀 강도를 정확하게 측정하기 위하여, 제 2 연구자가 실험 전에 대상 아동에게 혀로 벌브를 세게 누르라는 구어적인 지시를 하였으며, 혀로 세게 누를수록 기기의 수치가 변화되는 것을 시각적으로 보여주었다. 그 리고 IOPI의 지침서에 따라 일주일에 최소 1 번씩 IOPI의 교정(calibration)을 실시하였으며, 신뢰로운 데이터 수집을 위하여 대상자 의 혀 강도를 3 회 반복 측정하였다. 이때, 혀 피로도를 고려하여 매 측정 후에는 30초 이상의 휴식시간을 주었다(Potter \& Short, 2009).

\section{자음정확도 평가}

$\mathrm{APAC}$ 단어검사에서 평가자는 대상 아동이 혀 강도 측정 시와 동일하게 자세보조 의자에서 편안한 자세를 유지할 수 있도록 하였 으며, 아동이 편안한 자세에서 단어를 말할 수 있도록 그림의 위치 와 각도를 대상자에 맞추어서 조절하였다. 그리고 평가자는 아동 과 마주보고 앉은 상태에서 그림자료를 제시하면서 해당되는 단어 이름을 말하도록 유도하였다. 이때, 대상 아동의 발화는 디지털 레 코더(EDIROL R-05HR, Roland Inc., Osaka, Japan)와 단일 지향성 마이크(Shure MX183-X, Shure Inc., Washington, DC, USA)를 사 용하여 녹음하였다. 단어 전사는 언어재활사 1 급 자격증을 소지한 제1연구자가 조용한 장소에서 헤드폰(SONY MDR-ZX770AP, SONY Corp., Tokyo, Japan)을 착용한 상태에서 실시하였다.

\section{자료분석}

혀 강도는 IOPI의 LCD 창에 표시된 수치를 기준으로 하였으며, 신뢰로운 혀 강도 측정을 위해서 총 3 회에 걸쳐 측정된 수치 중에서 가장 높은 값으로 분석하였다(Robin, Somodi, \& Luschei, 1991). 자음정확도는 대상 아동의 반응이 목표음소와 일치한 경우 1 점, 불 
일치한 경우 0 점으로 채점하였으며, 아동이 정확하게 발음한 음소 의 개수를 전체 음소(70개), 조음위치(양순음, 치조음, 경구개음, 연 구개음, 성문음), 조음방법(파열음, 파찰음, 마찰음, 비음, 유음)에 따 른 목표음소수로 나눈 후에 100을 곱하여 0-100\%로 산출하였다.

\section{신뢰도}

자음정확도에 대한 평가자 간 신뢰도(inter-rater reliability)를 산 출하기 위해서, 연구자 외에 언어재활사 1 급자격증 소지자 1 명을 제 2 평가자로 참여시켰다. 연구자는 전체 자료의 $20 \%$ 에 해당하는 자 료를 무작위로 추출하여, 제2평가자에게 녹음자료를 듣고 개별적 으로 채점하도록 하였다. 연구자와 제 2 평가자가 채점한 결과를 비 교하여 평가자 간에 채점이 일치하는지 일치도(agreement)로 신뢰 도를 확인한 결과, 평가자 간 신뢰도는 $98.1 \%$ 로 나타났다.

\section{자료의 통계적 처리}

본 연구에서는 혀 강도에 따른 뇌성마비 아동의 집단 간에 조음 위치 및 조음방법에 따른 자음정확도에 유의한 차이가 있는지 살 펴보기 위해서, Kolmogorov-Smirnov 검정으로 정규성 검정(normality test)을 실시하였다. 그 결과, 고집단의 일부 조음위치와 조 음방법의 자음정확도가 정규성 가정에 위배되는 것으로 나타나서, 혀 강도에 따른 집단 간 자음정확도에 유의한 차이가 있는지 살펴 보기 위해 Mann-Whitney U-test를 실시하였다. 그리고 뇌성마비 아동의 혀 강도와 조음위치 및 조음방법에 따른 자음정확도와의 상관관계를 살펴보기 위해서 스피어만 등위상관분석(Spearman rank correlation)을 실시하였으며, 대상 아동의 혀 강도가 자음정 확도를 예측하는 변수인지 확인하기 위해 단순회귀분석(simple regression analysis)을 실시하였다. 본 연구의 자료는 IBM SPSS Sta- tistics version 23 (IBM Co., Armonk, NY, USA)을 이용하여 분석 하였다.

\section{연구결과}

\section{뇌성마비 아동의 혀 강도에 따른 자음정확도}

대상 아동의 혀 강도에 따른 집단의 조음위치와 조음방법에서의 자음정확도에 대한 기술통계 결과는 Table 2에 제시하였다.

집단간조음위치 및조음방법에 따른자음정확도차이를살펴보기 위해서 Mann-Whitney U-test를 실시한 결과, 모든 조음위치와 조음 방법에서 고집단의 자음정확도가 저집단에 비해서 유의하게 높았다 (all $p<.05$ ) (Figure 1). 세부적으로 살펴보면, 조음위치에서는 양순음

Table 2. Percentage of consonants correct (\%) according to the place and manner of articulation for children with higher tongue strength and children with lower tongue strength

\begin{tabular}{lcc}
\hline & High group $(\mathrm{N}=10)$ & Low group $(\mathrm{N}=10)$ \\
\hline Place of articulation & & \\
Bilabial & $93.75(62.50-100.00)$ & $18.75(.00-82.29)$ \\
Alveolar & $93.55(54.84-100.00)$ & $17.74(.00-86.29)$ \\
Palatal & $100.00(62.51-100.00)$ & $25.00(.00-83.33)$ \\
Velar & $100.00(64.99-100.00)$ & $33.33(.00-83.33)$ \\
Glottal & $100.00(87.50-100.00)$ & $25.00(.00-100.00)$ \\
Manner of articulation & & \\
Plosive & $94.65(68.75-100.00)$ & $28.75(.00-91.08)$ \\
Fricative & $75.00(50.00-100.00)$ & $5.00(.00-60.00)$ \\
Affricate & $100.00(62.51-100.00)$ & $25.00(.00-83.33)$ \\
Nasal & $97.37(63.16-100.00)$ & $18.42(.00-78.95)$ \\
Liquid & $100.00(53.57-100.00)$ & $21.43(.00-100.00)$ \\
\hline
\end{tabular}

Values are presented as median (interquartile range).
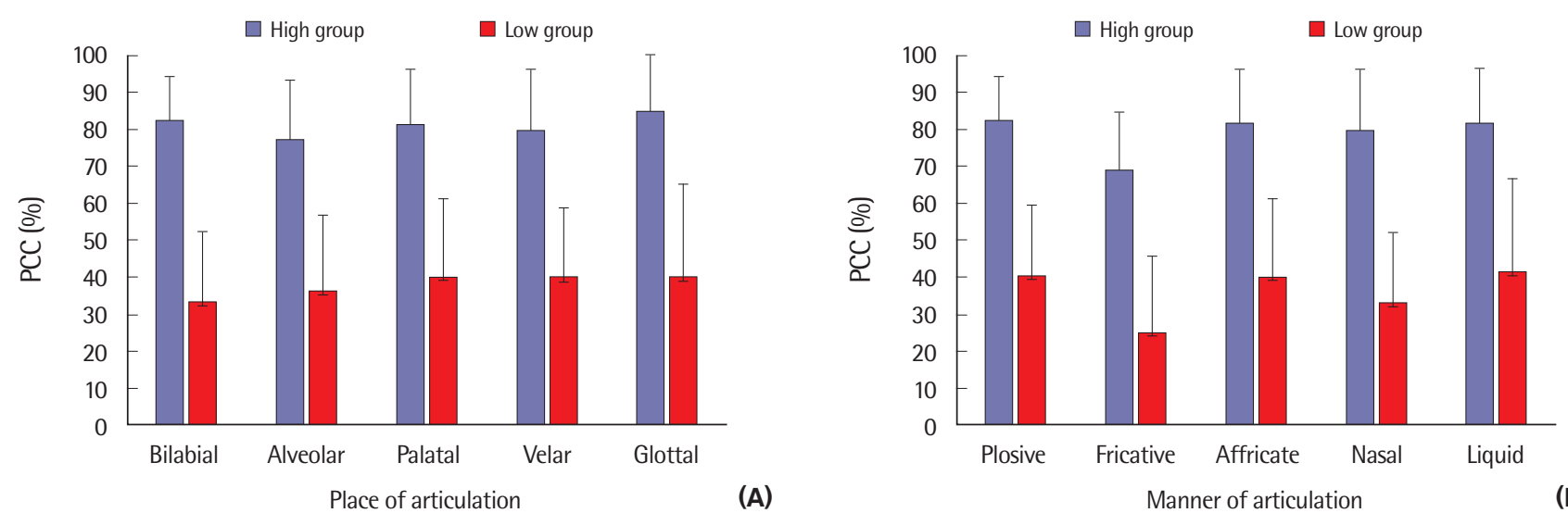

Figure 1. Percentage of consonants correct (PCC) according to the tongue strength for children with cerebral palsy. (A) PCC according to the group and place of articulation. (B) PCC according to the group and manner of articulation. 
Youngmee Lee, et al. • The Effects of Tongue Strength on Speech Production Skills

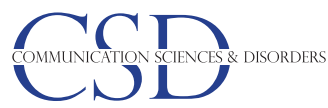

Table 3. Correlations between maximal tongue strength and PCC according to the place and manner of articulation for children with cerebral palsy ( $\mathrm{N}=20$ )

\begin{tabular}{|c|c|c|c|c|c|c|c|c|c|c|}
\hline & \multicolumn{5}{|c|}{ Place of articulation } & \multicolumn{5}{|c|}{ Manner of articulation } \\
\hline & $\begin{array}{l}\text { PCC for } \\
\text { bilabial }\end{array}$ & $\begin{array}{l}\text { PCC for } \\
\text { alveolar }\end{array}$ & $\begin{array}{l}\text { PCC for } \\
\text { palatal }\end{array}$ & $\begin{array}{l}\text { PCC for } \\
\text { velar }\end{array}$ & $\begin{array}{l}\text { PCC for } \\
\text { glottal }\end{array}$ & $\begin{array}{l}\text { PCC for } \\
\text { plosive }\end{array}$ & $\begin{array}{l}\text { PCC for } \\
\text { fricative }\end{array}$ & $\begin{array}{l}\text { PCC for } \\
\text { affricate }\end{array}$ & $\begin{array}{c}\text { PCC for } \\
\text { nasal }\end{array}$ & $\begin{array}{l}\text { PCC for } \\
\text { liquid }\end{array}$ \\
\hline Tongue strength & $.680^{* *}$ & $.565^{* *}$ & $.624^{* *}$ & $.607^{* *}$ & $.576^{* *}$ & $.607^{* *}$ & $.632^{* *}$ & $.624^{* *}$ & $.598^{* *}$ & $.549 * *$ \\
\hline
\end{tabular}

$\mathrm{PCC}=$ percentage of consonants correct.

${ }^{* *} p<.01$.

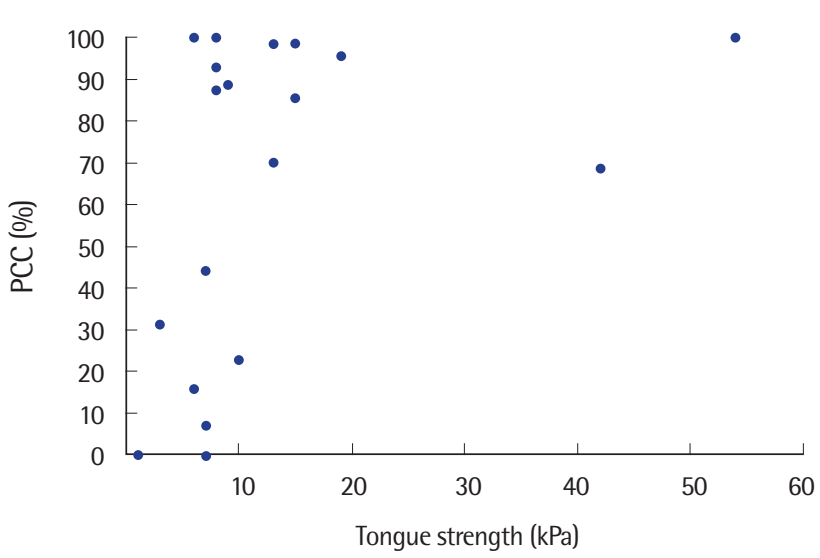

Figure 2. Scatterplot of the tongue strength and percentage of consonants correct (PCC) for children with cerebral palsy.

( $U=10.500, p<.01)$, 치조음 $(U=20.000, p<.05)$, 경구개음 $(U=19.000$, $p<.05)$, 연구개음 $(U=16.500, p<.01)$, 성문음 $(U=23.500, p<.05)$, 조음 방법에서는 파열음 $(U=20.500, p<.05)$, 마찰음 $(U=18.500, p<.05)$, 파 찰음 $(U=20.500, p<.05)$, 비음 $(U=15.500, p<.01)$, 유음 $(U=20.500$, $p<.05)$ 에서 집단간에 유의한차이가 있었다.

\section{뇌성마비 아동의 혀 강도와 자음정확도 간의 관계}

뇌성마비 아동의 혀 강도와 자음정확도 간의 상관관계를 살펴 보기 위해서 스피어만 등위상관분석을 실시한 결과, Spearman's rho의 범위가.549-.680으로, 혀 강도와 10 개의 조음위치 및 조음방 법에서의 자음정확도의 상관관계가 모두 유의한 것으로 나타났다 (all $p<.01$ ) (Table 3). 즉, 뇌성마비 아동의 혀 강도가 높을수록 모 든 조음위치 및 조음방법에서 자음정확도가 유의하게 증가되는 양 상을 보였다. 그리고 뇌성마비 아동의 혀 강도와 자음정확도는 유 의한 상관을 보여서 $(r=.651, p<.01)$, 혀 강도가 높을수록 자음정확 도가 유의하게 높았다(Figure 2). 혀 강도가 자음정확도에 미치는 영향을 살펴보기 위해서 단순 회귀분석을 실시한 결과, 혀 강도 $(\beta=.448, p<.05$ )가 뇌성마비 아동의 자음정확도를 약 $20.1 \%$ (수정 계수에 의하면 $15.7 \%)$ 설명하는 것으로 나타났다 $\left(F_{(1,18)}=4.525\right.$, $\left.p<.05, \mathrm{R}^{2}=.201\right)$.

\section{논의 및 결론}

말장애인의 비구어 구강운동 기능과 말 산출 능력 간의 관련성 에 대해서 연구자 간의 이견이 있음에도 불구하고, 상당수의 언어 재활전문가들은 뇌성마비 아동의 정확한 말 산출 능력 평가를 위 해서 비구어 구강운동 기능에 대한 평가도 함께 실시하고 있으며, 말명료도 개선을 위해서 비구어 구강운동 접근을 구어 접근과 함 께 병행하고 있다. 본 연구에서는 뇌성마비 아동의 혀 강도와 말 산 출 능력 간의 관련성을 탐색하여, 임상 현장에서 시행되는 비구어 구강운동 접근의 선택과 적용에 필요한 정보를 제공하고자 하였다.

본 연구에서 혀 강도를 기준으로 뇌성마비 아동을 두 집단으로 구분하여 자음정확도를 비교한 결과, 혀 강도가 높은 집단의 자음 정확도가 모든 조음위치와 조음방법에서 혀 강도가 낮은 집단에 비해 유의하게 높았다. 이러한 결과는 마비말장애 성인의 혀 강도와 말 산출 능력과의 관련성을 보고한 선행연구(Choi \& Sim, 2013; Lee et al., 2005)의 결과와 일치한다. Choi와 $\operatorname{Sim}$ (2013)이 말명료도 에 따라 마비말장애 성인을 경도, 중등도, 고도로 집단을 구분하고 일반 성인과의 혀 강도의 차이를 살펴본 결과, 말명료도 수준이 중 등도와 고도인 마비말장애 성인의 혀 강도가 일반 성인과 경도인 마비말장애 성인에 비해서 유의하게 낮았다. Theodoros, Murdoch 와 Strokes (1995)가 외상성 뇌손상(traumatic brain injury) 후 마비 말장애가 온 성인의 혀 기능을 일반 성인과 비교한 결과에서도 후 천성 마비말장애인의 혀 기능이 정상 성인에 비해서 저하되어 있었 다. 마비말장애 성인을 대상으로 한 연구 외에 발달적 구어 실행증 (developmental verbal apraxia) 아동을 대상으로 혀 강도를 측정한 Murdoch 등(1995)의 연구에서도 일반 아동에 비해서 발달적 구어 실행증 아동의 혀 강도가 유의하게 낮은 것으로 나타났다. 이러한 연구 결과는 말장애 원인과 연령에 무관하게 말장애군에서는 혀 기능의 약화가 나타날 수 있으며, 말장애인의 혀 기능의 저하가 말 산출에 부정적인 영향을 미칠 수도 있다는 것을 의미한다.

뇌성마비 아동의 혀 강도와 조음위치와 조음방법에 따른 자음 정확도 간의 상관계수 범위가 .549-.680에 해당되어 중등도 수준의 유의한 상관을 보여서(Rosner, 2000), 뇌성마비 아동의 혀 강도가 
낮을수록 자음정확도가 떨어지는 것으로 나타났다. 이는 뇌성마 비 아동의 근육 수축 작용, 신경근 접합부(neuromuscular junctions) 및 운동뉴런(motor neuron) 등의 결함으로 인한 혀 기능의 저하가 말 산출 능력에 부정적인 영향을 미칠 수 있음을 반영하는 결과이다(Luschei, 1991). 또한, 이러한 결과는 앞서 언급한 선행연 구(Choi \& Sim, 2013; Lee et al., 2005; Murdoch et al., 1995; Theodoros et al., 1995)와 함께 정상적인 말 산출을 위해서 구강감각운동 의 과정이 중요하다는 말 운동 통제모델의 입장을 지지하는 연구 결과라 할 수 있다(Sim, 2001). 뇌성마비 아동의 혀 강도 외에도 씹 기 기능과 말 산출 능력과의 관련성에 대해서 보고한 선행연구 (Chang et al., 2012; Jeong \& Sim, 2015; Kim, Ahn, \& Kwon, 2008)에 서도 일관되게 뇌성마비 아동의 비구어 구강운동 기능이 말 산출 능력과 관련이 있다고 보고되고 있다. Chang 등(2012)은 경직형 뇌 성마비 아동의 정상적인 씹기 점수가 말명료도와 유의한 상관을 보여서, 뇌성마비 아동을 위한 비구어 구강운동 훈련이 말명료도 향상에 도움이 될 수 있을 것이라고 하였다. Jeong과 Sim (2015)이 경직형 뇌성마비 아동의 씹기 능력을 경도, 중등도, 심도로 구분하 여 말명료도를 비교한 결과, 씹기 능력이 심도인 뇌성마비 아동의 말명료도가 경도, 중등도인 뇌성마비 아동에 비해서 유의하게 낮 았다. 그리고 Kim과 Ahn 등(2008)의 연구에서도 경직형 뇌성마비 아동의 섭식과 관련된 입술, 혀, 턱 운동 능력과 조음정확도 간에 유의한 상관을 보였다. 이러한 연구결과는 뇌성마비 아동의 혀뿐 만 아니라 입술, 턱의 움직임과 관련된 비구어 구강운동 능력의 결 함이 정상적인 말 산출에 부정적인 영향을 미칠 수 있다는 것을 시 사한다. 말 산출 이전 과정에서부터 습득하게 되는 입술, 혀, 턱의 운동과정이 정상적으로 확장되고 발달되지 않으면, 말 산출을 위 한 기초적인 기술 습득에 지속적인 영향을 미칠 수 있음을 의미한 다(MacNeilage, 1998).

뇌성마비 아동의 비구어 구강운동과 말 산출 능력과의 관련성 을 살펴보기 위해서 중재 연구가 진행되기도 하였다. 뇌성마비 아 동을 대상으로 비구어 구강운동 능력 향상을 목표로 한 중재 연구 (Jeon \& Seo, 2007; Kim, Kim, et al., 2008; Kim \& Paek, 2017; Ray, 2001)에서 말 산출 능력까지 향상되는 결과가 보고되었다. Kim과 Paek (2017)은 경직형 뇌성마비 아동에게 구강운동을 실시한 결과, 중재 전에 비해 조음기관의 기능, 모음정확도, 자음정확도가 향상 된 결과를 제시하면서, 뇌성마비 아동의 말 산출 능력 향상을 위해 서 개별화된 비구어 구강운동 치료 프로그램의 개발과 지속적인 중재가 필요하다고 하였다. Ray (2001)는 비구어 구강운동을 통해 구강기능이 향상되었을 뿐만 아니라 호흡 및 섭식기능까지 변화하 였으므로, 구강근육의 훈련을 통해 말 산출 능력을 촉진시킬 수 있
다고 보았다. 이러한 긍정적인 중재 효과 보고는 뇌성마비 아동(Jeon \& Seo, 2007; Kim, Kim, et al., 2008; Kim \& Paek, 2017; Ray, 2001) 뿐만 아니라 마비말장애 성인(Ray, 2002), 치아 문제로 발음 오류가 있는 성인(Ray, 2003)에게도 일관되게 보고되어, 임상현장에서 말 산출 능력 향상을 위한 비구어 구강운동 접근법 실시에 대한 근거 를 제공하였다. 이렇듯 다양한 장애군에서 비구어 구강운동 훈련 의 효과가 도출되었다는 점을 고려할 때, 비구어 구강운동 접근법 을 말장애를 지닌 광범위한 장애군에 적용하여 말 산출 능력의 개 선까지 기대해 볼 수 있을 것으로 생각된다.

본 연구에서는 혀 강도가 뇌성마비 아동의 말 산출에 미치는 영 향을 세부적으로 살펴보기 위해서, 자음정확도를 조음위치와 조 음방법에 따라 구분하여 집단비교와 상관분석을 실시하였다. 그 결과, 혀 강도에 따라 구분한 뇌성마비 아동 집단 간 자음정확도가 모든 조음위치와 조음방법에서 유의한차이를 보였으며, 전체 뇌성 마비 아동의 혀 강도가 모든 조음위치와 조음방법에서의 자음정 확도와 유의한 상관을 보였다. 본 연구에서는 혀의 운동 기능과 직 접적인 관련성이 적은 양순음의 자음정확도가 혀 강도와 유의한 상관을 보였다. 자음 산출 과정을 살펴보면, 자음은 발동, 발성 과 정을 거친 기류가 구강에서 조음 과정을 거쳐 산출되며, 이때, 기류 가 구강 내 어느 위치에서 어떠한 방해를 받았느냐에 따라서 산출 되는 자음이 달라지게 된다. 이처럼 자음은 혀의 정교하고 미묘한 움직임의 차이로 다른 말소리로 산출되기 때문에, 뇌성마비 아동 의 혀의 기능 저하가 특정 위치와 방법에서의 자음 산출에만 영향 을 미치기는 힘들 것으로 생각된다. 즉, 혀의 기능의 약화로 혀를 정 교하게 좌우, 상하로 적절한 운동범위로 움직일 수 없다면, 다양한 조음위치와 조음방법으로 자음을 산출하기가 어렵게 되는 것이다 (Lee et al., 2005). 또한, 정확한 자음 산출에는 혀뿐만 아니라, 입술 과 혀의 협응, 턱의 조절 능력이 함께 필요하기 때문에, 조음 기관의 구강운동 상호 영향을 받아서 혀의 강도와 양순음에서의 자음정 확도 간에 유의한 상관이 나타난 것으로 생각된다(Green, Moore, \& Reilly, 2002). 그리고 단어 내 양순파열음은 단독 말소리의 형태 가 아니라 모음과 결합된 상태에서 산출이 되었기 때문에, 모음 산 출에 필요한 혀의 움직임이 함께 작용하여 혀가 양순음의 산출에 영향을 미쳤을 수도 있었을 것으로 생각된다(Kim \& Paek, 2017).

본 연구에서 주목할 점은 회귀분석 결과에서 뇌성마비 아동의 혀 강도가 자음정확도를 약 $20.1 \%$ 설명할 수 있는 유의한 변수로 도출되었다는 점이다. 이러한 결과는 혀 강도와 말 산출 능력이 통 계적으로 유의한 상관이 없다고 보고한 선행연구(Bunton, 2008; Neel \& Palmer, 2012)와 상반되는 결과이다. Neel과 Palmer (2012) 의 연구에 따르면, 정상적인 말 산출 능력을 지닌 건강한 성인의 혀 
Youngmee Lee, et al. • The Effects of Tongue Strength on Speech Production Skills

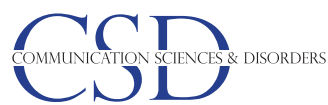

강도는 읽기과제에서의 조음속도를 예측할 수 있는 유의한 변수가 아니었다. 이러한 상반된 연구 결과는 대상자의 특성과 관련 있을 것으로 생각된다. 말 문제가 없는 건강한 성인의 경우, 말 산출에 필 요한 혀 강도가 최대 혀 강도의 $10-20 \%$ 에 불과하기 때문에(Bunton \& Weismer, 1994), 건강한 성인을 대상으로 한 Neel과 Palmer (2012)의 연구에서는 혀 강도가 조음속도에 미치는 영향이 미비했 을 것이다. 하지만, 본 연구에서는 조음중증도가 다양한 뇌성마비 아동을 대상으로 혀 강도를 측정하였기 때문에, 혀 근육의 약화로 인한 미세한 혀 강도의 차이가 자음정확도에 영향을 미쳤을 것으 로 보인다. 즉, 뇌성마비 아동의 말 산출 능력은 혀 근육을 정교하게 움직이고 적절하게 힘을 유지하는 비구어 운동 능력에 영향을 받 는 것이다.

본 연구를 통해, 혀 강도가 뇌성마비 아동의 말 산출 능력을 예 측하는 역할을 하는 평가 지표뿐만 아니라 치료 효과의 척도로의 가능성을 탐색하였다(Adams et al., 2013; Murdoch et al., 1995; Ray, 2001). 이러한 결과는 임상 현장에서 뇌성마비 아동의 정확한 말 산출 능력의 평가와 전반적인 치료 접근법 결정을 위해서 혀 강도 평가 결과를 활용할 필요가 있다는 것을 의미한다. 또한, 혀 기능을 측정하는 IOPI와 같은 도구를 사용하는 객관적인 방법이 언어재 활사의 행동관찰적 방법과 함께 뇌성마비 아동의 진단과 치료에 유용하게 활용될 수 있음을 시사한다. 하지만, 본 연구는 대상자의 수가 적고, 주로 경직형 뇌성마비 아동을 대상으로 하여, 다른 유형 의 뇌성마비 아동에게 연구결과를 일반화하는 것에는 한계가 있 다. 또한, 뇌성마비 아동의 발화를 정조음과 오조음의 이분법적인 채점방식으로 자음정확도를 산출하여 분석하였기 때문에, 뇌성마 비 아동의 말 특성에 근거하여 혀 강도와의 관련성을 살펴보는 데 한계가 있었다. 그리고 본 연구에서는 말 산출에 관여될 수 있는 다 양한 비구어 운동 능력 중에서 혀 강도에만 초점을 맞추었기 때문 에, 입술, 혀, 턱 등의 비구어 구강운동 기능들이 상호 간에 어떠한 관련성을 지니면서 말 산출에 영향을 미치는지에 대한 설명을 할 수는 없었다. 그러므로 향후 연구에서는 많은 수의 뇌성마비 아동 을 대상자로 포함시키며, 뇌성마비 유형에 따라 다양한 비구어 운 동 기능들이 말 산출에 미치는 영향을 살펴볼 필요가 있겠다. 그리 고 뇌성마비 아동의 조음오류 유형에 따른 비구어 운동 능력을 탐 색하여, 분절적 차원의 조음오류 형태와 비구어 운동 능력 간의 관 련성을 확인할 필요도 있을 것이다.

\section{REFERENCES}

Adams, V., Mathisen, B., Baines, S., Lazarus, C., \& Callister, R. (2013). A sys- tematic review and meta-analysis of measurements of tongue and hand strength and endurance using the Iowa Oral Performance Instrument (IOPI). Dysphasia, 28, 350-369.

Ansel, B. M., \& Kent, R. D. (1992). Acoustic-phonetic contrasts and intelligibility in the dysarthria associated with mixed cerebral palsy. Journal of Speech and Hearing Research, 35, 296-308.

Bunton, K. (2008). Speech versus nonspeech: different tasks, different neural organization. Seminars in Speech and Language, 29, 267-275.

Bunton, K., \& Weismer, G. (1994). Evaluation of a reiterant force-impulse task in the tongue. Journal of Speech, Language, and Hearing Research, 37, 1020-1031.

Caruso, A. J., \& Strand, E. A. (1999). Motor speech disorders in children: definitions, background and a theoretical framework. In A. J. Caruso \& E. A. Strand (Eds.), Clinical management of motor speech disorders in children (pp. 1-27). New York, NY: Thieme.

Chang, S. J., Sim, H. S., \& Kwon, M. S. (2012). Relationship between chewing skill and speech intelligibility in Korean children with spastic cerebral palsy. Japan Journal Logopedics and Phoniatrics, 53, 20-26.

Choi, Y., \& Sim, H. (2013). Relationship between the maximal tongue and lip strength and percentage of correct consonants and speech intelligibility in dysarthric adults with cerebral palsy. Phonetics and Speech Sciences, 5, 1122.

Clark, H. M., \& Solomon, N. P. (2012). Age and sex differences in orofacial strength. Dysphasia, 27, 2-9.

Darley, F. L., Brown, J. R., \& Aronson, A. E. (1975). Motor speech disorders. Philadelphia, PA: Saunders.

Green, J. R., Moore, C. A., \& Reilly, K. J. (2002). The sequential development of jaw and lip control for speech. Journal of Speech and Hearing Research, $45,66-79$.

Hiiemae, K. M., \& Palmer, J. B. (2003). Tongue movements in feeding and speech. Critical Reviews in Oral Biology \& Medicine, 14, 413-429.

Jeon, B. U., \& Seo, J. E. (2007). The effect of respiration and oral motor training on correctness of consonants and the vocalization prolongation for children with spastic cerebral palsy. Korean Journal of Physical, Multiple, \& Health Disabilities, 49, 135-160.

Jeong, P. Y., \& Sim, H. S. (2015). The influence of chewing ability on speech intelligibility in children with spastic cerebral palsy. Special Education Research, 14, 63-80.

Kim, M. J., Pae, S., \& Park, C. I. (2007). Assessment of phonology for children (APAC). Incheon: Human Brain Research \& Consulting Co. 
Kim, S. H., Ahn, J. B., \& Kwon, D. H. (2008). A correlation studying between feeding skills and percent of correct articulation of the children with spastic cerebral palsy. Journal of Speech-Language \& Hearing Disorders, 17, 1-17.

Kim, S. H., Kim, H. G., \& Shin, Y. I. (2008). The effect of the treatment on the pre- and post- respiration and the oral motor for children with cerebral palsy by acoustic analysis. Speech Sciences, 15, 131-141.

Kim, S. H., \& Paek, H. H. (2017). Effect of treatment on oral motor for children with spastic cerebral palsy. Journal of Korea Entertainment Industry Association, 11, 211-218.

Lee, J. H., Koo, J. H., Jang, D. H., Park, E. H., \& Sung, I. Y. (2006). The functional prognosis of ambulation in each type of cerebral palsy. Annals of Rehabilitation Medicine, 30, 315-321.

Lee, K. H., Sim, H. S., \& Kim, H. H. (2005). Tongue strength, range of motion, and speech intelligibility in dysarthric speakers. Speech Sciences, 12, 89-99.

Lee, S. K., \& Kim, S. S. (2017). Effects of articulation therapy using oral motor training on the articulation accuracy and the lateralization distortion errors of children with class III malocclusion. Audiology and Speech Research, 13, 361-371.

Love, R. J., Hagerman, E. L., \& Taimi, E. G. (1980). Speech performance, dysphagia and oral reflexes in cerebral palsy. Journal of Speech Hearing Disorders, 45, 59-75.

Luschei, E. (1991). Development of objective standards of nonspeech oral strength and performance. In C. A. Moore et al. (Eds.), Dysarthria and apraxia of speech; perspectives on management (pp. 3-14). Baltimore, MD: Paul H. Brookes Publishing.

Mackenzie, C., Muir, M., \& Allen, C. (2010). Non-speech oro-motor exercise use in acquired dysarthria management: regimes and rationales. International Journal of Language and Communication Disorders, 45, 617-629.

Mackenzie, C., Muir, M., Allen, C., \& Jensen, A. (2014). Non-speech oro-motor exercises in post-stroke dysarthria intervention: a randomized feasibility trial. International Journal of Language and Communication Disorders, 49, 602-617.

MacNeilage, P. F. (1998). The frame/content theory of evolution of speech production. Behavioral and Brain Science, 21, 499-546.

Morris, S. E., \& Klein, M. D. (1987). Pre-feeding skills. Tucson, AZ: Therapy Skill Builders.

Morris, S. E., \& Klein, M. D. (2000). Pre-feeding skills (2nd ed.). San Antonio, TX: Therapy Skill Builders.

Murdoch, B. E., Attard, M. D., Ozanne, A. E., \& Stokes, P. D. (1995). Impaired tongue strength and endurance in developmental verbal dyspraxia: a physiological analysis. European Journal of Disorders of Communication, 30, 5164.

Muttiah, N., Georges, K., \& Brackenbury, T. (2011). Clinical and research perspectives on nonspeech oral motor treatments and evidence-based practice. American Journal of Speech-Language Pathology, 20, 47-59.

Neel, A. T., \& Palmer, P. M. (2012). Is tongue strength an important influence on rate of articulation in diadochokinetic and reading tasks? Journal of Speech, Language, and Hearing Research, 55, 235-246.

Potter, N. L., \& Short, R. (2009). Maximal tongue strength in typically developing children and adolescents. Dysphagia, 24, 391-397.

Ray, J. (2001). Functional outcomes of orofacial myofunctional therapy in children with cerebral palsy. The International Journal of Orofacial Myology, 27, 5-17.

Ray, J. (2002). Orofacial myofunctional therapy in dysarthria: a study on speech intelligibility. The International Journal of Orofacial Myology, 28, 39-48.

Ray, J. (2003). Effects of orofacial myofunctional therapy on speech intelligibility in individuals with persistent articulatory impairments. The International Journal of Orofacial Myology, 29, 5-14.

Robin, D. A., Goel, A., Somodi, L. B., \& Luschei, E. S. (1992). Tongue strength and endurance: relation to highly skilled movements. Journal of Speech and Hearing Research, 35, 1239-1245.

Robin, D. A., Somodi, L. B., \& Luschei, E. S. (1991). Measurement of strength and endurance in normal and articulation disordered subjects. In C. A. Moore et al. (Eds.), Dysarthria and apraxia of speech: perspectives on management (pp. 173-184). Baltimore, MD: Paul H. Brookes Publishing.

Rosner, B. (2000). Fundamentals of biostatics (5th ed.). Pacific Grove, CA: Duxbury.

Sim, H. S. (2001). Speech motor approaches to speech disorders: a critique of literature. Korean Journal of Special Education, 35, 121-141.

Song, Y. (2014). Characteristics of maximal tongue and lip strength and tongue endurance scores according to age and gender in healthy Korean adults. Phonetics and Speech Sciences, 6, 97-106.

Steeve, R., Moore, C., Green, J., Reilly, K., \& McMurtrey, J. (2008). Babbling, chewing and sucking: oromandibular coordination at 9 months. Journal of Speech, Language, and Hearing Research, 51, 1390-1404.

Theodoros, D. G., Murdoch, B. E., \& Stokes, P. (1995). A physiological analysis of articulatory dysfunction in dysarthric speakers following severe closed head injury. Brain Injury, 9, 237-254.

Van Lierde, K., Galiwango, G., Hodges, A., Bettens, K., Luyten, A., \& Vermeersch, 
Youngmee Lee, et al. • The Effects of Tongue Strength on Speech Production Skills

H. (2012). Impact of tongue reduction on overall speech intelligibility, articulation and oromyofunctional behavior in 4 children with BeckwithWiedemann syndrome. Follia Phoniatrica et Logopaedica, 64, 55-63.

Vitorino, J. (2010). Effect of age on tongue strength and endurance scores of healthy Portuguese speakers. International Journal of Speech-Language Pathology, 12, 237-243.
Watson, M. M., \& Lof, G. L. (2008). Epilogue: what we know about nonspeech oral motor exercises. Seminars in Speech and Language, 29, 339344.

Workinger, M. S. (2005). Cerebral palsy resource guide for speech-language pathologists. Clifton Park, NY: Thomson Delmar Learning. 


\section{국문초록}

\section{혀 강도가 뇌성마비 아동의 말 산출에 미치는 영향}

이영미'(교수, 제1저자) · 정필연2(학생) · 성지은(교수) · 심현섭(교수, 교신저자)

'동명대학교 언어치료학과, ${ }^{2}$ 이화여자대학교 대학원 언어병리학과

배경 및 목적: 본 연구에서는 혀 강도가 뇌성마비 아동의 자음 산출에 미치는 영향을 살펴봄으로써, 뇌성마비 아동의 말 평가와 재활 계획 수립에 유용한 정보를 제공하고자 한다. 방법: 본 연구에서는 검사 당시 연령이 5-15세인 뇌성마비 아동 20명을 대상으로 하였다. 대상 아동의 조음위치 및 조음방법에 따른 자음정확도는 아동용 발음평가를 이용하여 평가하였으며, 혀 강도는 Iowa Oral Performance Instrument (IOPI)를 사용하여 평가하였다. 결과: 혀 강도를 기준으로 뇌성마비 아동을 중앙치 반분법에 따라 고집단(10명)과 저집단(10명)으로 나누어서 Mann-Whitney U-test를 실시한 결과, 모든 조음위치와 조음방법에서 고집단의 자음정확도가 저집단에 비해 유의하게 높았다. 전체 뇌성마비 아동을 대상으로 혀 강도, 조음위치 및 조음방법에서의 자음정확도 간의 상관계수의 범위는 .549.680 이었으며(all $p<.01)$, 뇌성마비 아동의 혀 강도는 단어 수준에서의 자음정확도를 유의하게 예측하는 변수로 나타났다 $(p<.05)$. 논 의 및 결론: 혀 강도가 높은 뇌성마비 아동이 낮은 아동에 비해서 더 정확하게 자음을 산출할 수 있었으며, 뇌성마비 아동의 혀 강도는 말 산출 능력을 예측할 수 있는 유의한 변수였다.

핵심어: 뇌성마비, 아동, 혀 강도, 자음정확도

본 연구는 지식경제부 및 한국산업기술평가관리원의 기술혁신사업의 일환으로 수행하였음(No. 10036461, 발성 장애인을 위한 개인 맞춤형 내장형 명령어 인식기 개발).

본 연구는 2012년 한국언어청각임상학회에서 발표한 내용의 일부를 포함하고 있음.

\section{참고문헌}

김민정, 배소영, 박창일(2007). 아동용 발음평가(APAC). 인천: 휴브알앤씨.

김선희, 안종복, 권도하(2008). 경직형 뇌성마비 아동들의 섭식 기능과 조음정확도 간의 상관연구 언어치료연구, 17, 1-17.

김숙희, 김현기, 신용일(2008). 음향학적 분석을 통한 뇌성마비 아동의 호흡 및 구강운동 전후치료효과.음성과학, 15, 131-141.

김숙희, 백현희(2017). 경직형 뇌성마비 아동의 구강운동 치료 효과. 한국엔터테인먼트산업학회논문지, 11, 211-218.

송윤경(2014). 세대 및 성별에 따른 한국인의 최대 혀 및 입술 강도와 혀 지구력 측정치 특성. 말소리와 음성과학, 6, 97-106.

심현섭(2001). 말장애 연구의 동향에 관한 고찰: 말 운동 통제모델을 중심으로. 특수교육학연구, 35, 121-141.

이경하, 심현섭, 김향희(2005). 마비말장애 환자의 혀의 강도, 운동 범위와 말명료도에 관한 연구. 음성과학, 12, 89-99.

이상경, 김성수(2017). 구강운동 훈련을 사용한 조음치료가 3 급 부정교합 아동의 조음 정확도 향상과 설측음화 왜곡 오류 감소에 미치는 효과. 청능 재활연구, 13, 361-371.

이정환, 구정희, 장대현, 박은하, 성인영(2006). 뇌성마비 유형에 따른 보행 기능의 예후. 대한재활의학회지, 30, 315-321.

전병운, 서정은(2007). 호흡 및 구강운동훈련이 경직형 뇌성마비아동의 자음정확도와 발성호기 시간에 미치는 효과. 지체·중복·건강장애연구, 49 ,

135-160.

정필연, 심현섭(2015). 경직형 뇌성마비아동의 씹기능력에 따른 말명료도의 변화. 특수교육, 14, 63-80.

최여진, 심현섭(2013). 뇌성마비로 인한 마비말장애 성인의 최대 혀 및 입술 강도와자음정확도 및 말명료도의 관계. 말소리와음성과학, 5, 11-22. 